\title{
Use of glacial and terrestrial habitats by harbor seals in Glacier Bay, Alaska: costs and benefits
}

\author{
Gail M. Blundell ${ }^{1, *}$, Jamie N. Womble ${ }^{2,3}$, Grey W. Pendleton ${ }^{1}$, \\ Shawna A. Karpovich ${ }^{4}$, Scott M. Gende ${ }^{3}$, Jason K. Herreman ${ }^{5}$ \\ ${ }^{1}$ Division of Wildlife Conservation, Alaska Department of Fish and Game, Juneau, Alaska 99811-0024, USA \\ ${ }^{2}$ Department of Fisheries and Wildlife, Marine Mammal Institute, Oregon State University, Newport, Oregon 97365 USA \\ ${ }^{3}$ Glacier Bay Field Station, National Park Service, Juneau, Alaska 99801 USA \\ ${ }^{4}$ Division of Wildlife Conservation, Alaska Department of Fish and Game, Fairbanks, Alaska 99701-1599 USA \\ ${ }^{5}$ Department of Zoology and Physiology, University of Wyoming, Laramie, Wyoming 82071 USA
}

\begin{abstract}
Among pinnipeds, harbor seals Phoca vitulina have the broadest distribution (a $34^{\circ}$ to $50^{\circ}$ range in latitudes in the Pacific and Atlantic regions, respectively) and are found in a diversity of habitats. Harbor seals in Alaska, USA, similar to Arctic pinnipeds in many respects, rely upon glacial ice for pupping, mating, and molting. Just as climate change affects Arctic sea ice, tidewater glaciers are rapidly retreating in Alaska, reducing ice availability for harbor seals. An increased understanding of glacial vs. terrestrial harbor seals may reveal information important to conservation of harbor seals and Arctic pinnipeds, as effects of climate change continue. We compared foraging distances, activity budgets, diet, and body condition for seals captured at glacial and terrestrial sites in Glacier Bay, Alaska. Foraging strategies and activity budgets of seals using glacial ice differed substantially from seals using terrestrial sites. Glacial seals traveled significantly farther to forage ( $\geq 40 \mathrm{vs} .<5 \mathrm{~km})$ and spent more time hauled out than terrestrial seals (26 vs. 11 to $16 \%$ ). Diets of glacial seals were higher in pelagic fishes compared to diets of terrestrial seals that foraged primarily on intertidal/demersal fishes. Body condition of seals was similar between habitats ( $p \geq 0.09)$ and suggests that costs of longer foraging trips for glacial seals may be offset by obtaining higher quality diets of pelagic fishes, which may allow seals to spend more time hauled out. During the brief lactation period, more time hauled out could result in more time available for the transfer of energy from adult females to dependent offspring.
\end{abstract}

KEY WORDS: Foraging behaviour - Activity budget · Body condition · Habitat use $\cdot$ Stable isotopes Time-depth recorder $\cdot$ Phocid $\cdot$ Pinniped

\section{INTRODUCTION}

Harbor seals Phoca vitulina are upper trophic level predators (Hobson et al. 1997, Pauly et al. 1998) that can function as an important indicator of the condition of marine ecosystems (e.g. Ross 2000, Boyd \& Murray 2001, Mos et al. 2006). Among pinnipeds, harbor seals have the broadest distribution (from approximately $30^{\circ}$ to $80^{\circ} \mathrm{N}$ in the eastern Atlantic region and from $28^{\circ}$ to $62^{\circ} \mathrm{N}$ in the eastern Pacific region) and occur in diverse habitats (Perrin et al. 2002). Throughout most of their distribution, harbor seals haul out in a variety of terrestrial habitats, but in coastal Alaska, USA, and Green- land, harbor seals also haul out on icebergs calved from tidewater glaciers. In Alaska, glacial fjords scattered along the southeastern and south central coasts currently host some of the largest seasonal aggregations of harbor seals in the world, and approximately 10 to $15 \%$ of the harbor seal population in Alaska are estimated to use glacial ice sites during the annual molt (Bengston et al. 2007).

Previous studies of harbor seals in Alaska have focused primarily on seals at terrestrial sites (e.g. Lowry et al. 2001, Hastings et al. 2004, Small et al. 2005); however, seasonal aggregations of harbor seals at some tidewater glaciers include disproportionately large 
numbers of pupping harbor seals (Calambokidis et al. 1987), suggesting that these sites provide important pupping and breeding habitats. Steep declines in harbor seal numbers have occurred at several glacial ice sites in Alaska (Hoover-Miller 1994, 2011, Mathews \& Pendleton 2006, Womble et al. 2010), highlighting the need for a better understanding of the basic ecology of seals using glacial habitat and the potential benefits and costs of using glacial ice to pup, breed, or molt.

Glacier Bay National Park seasonally hosts one of the largest aggregates of harbor seals in Alaska. Seals use both terrestrial substrate and glacial ice within the Bay, which provides a unique opportunity to understand the role of different habitats in influencing seal behavior within a relatively small geographic region. Also of interest is whether a comparison of seals in ice and terrestrial habitats can be used as a corollary to the situation in the Arctic as it relates to diminishing sea ice (Rodrigues 2009, Polyak et al. 2010) and Arctic phocids that rely upon ice substrate for resting, foraging, and reproduction (Kovacs \& Lydersen 2008, Laidre et al. 2008, Moore \& Huntington 2008).

Just as climate change affects ice availability for Arctic marine mammals (Tynan and DeMaster 1997, Laidre et al. 2008), tidewater glaciers in Alaska are rapidly melting and retreating (Arendt et al. 2002, Molnia 2007). Historical evidence suggests that harbor seals may already have been affected by declining ice availability in Glacier Bay, a recently deglaciated estuarine fjord in southeastern Alaska. A $10 \mathrm{~km}$ retreat of Muir Glacier in Glacier Bay resulted in a decrease in the number of harbor seals using Muir Inlet and an increase in the number of seals using glacial ice in Johns Hopkins Inlet and terrestrial sites in the Bay (Calambokidis et al. 1987). Following the grounding of Muir Glacier in 1993 (Hall et al. 1995), a 63 to $75 \%$ decline in seal numbers was documented in glacial and terrestrial sites, respectively, from 1992 to 2002 (Mathews \& Pendleton 2006); declines continued at a similar annual rate through 2008 (Womble et al. 2010). Despite ongoing declines, as of 2008, approximately 2000 harbor seals were counted in Glacier Bay, with 300 to 400 pups born each year on glacial ice in 2007 and 2008 (Womble et al. 2010).

Pupping season in Glacier Bay extends from approximately 22 May through 1 July and encompasses historic peaks in pup counts in Glacier Bay (Mathews \& Pendleton 2006) and a 3 to $5 \mathrm{wk}$ lactation period (Hoover 1983, Muelbert \& Bowen 1993, Hedd et al. 1995, Thompson \& Wheeler 2008). Harbor seals come into estrus near the end of lactation (Boness et al. 2006), and parturient harbor seals that use terrestrial habitats generally forage during the latter stages of lactation (Bowen et al. 1994, 2001), but the behavior of lactating glacial seals is unknown.
Hypotheses that have been proposed to explain benefits to harbor seals that use tidewater glaciers suggest that this type of haulout substrate (1) is relatively abundant, (2) is accessible at all times and tides, and (3) its use may reduce susceptibility to predation in comparison to terrestrial sites (Calambokidis et al. 1987). In this study we tested the accessibility hypothesis by examining timing of hauling out relative to tides, comparing seals that use terrestrial and glacial habitat within Glacier Bay. Further, approximately two-thirds of the seals in Glacier Bay use glacial ice (Mathews \& Pendleton 2006, Womble et al. 2010), which suggests that seals may experience additional benefits by using this habitat. Accordingly, we assessed whether use of different habitats resulted in different foraging strategies or diets and evaluated whether activity budgets, diet and body condition elucidated differences that suggest use of glacial habitat may be a more profitable strategy. Our ultimate objective is to better understand the importance of ice habitat to seals in order to enhance our ability to predict population-level and regional impacts as loss of glacial and sea ice continues.

\section{MATERIALS AND METHODS}

Study area. Glacier Bay National Park is located in the northern portion of the Alexander Archipelago in Southeast Alaska $\left(58^{\circ} 30.021^{\prime} \mathrm{N}, 135^{\circ} 54.072^{\prime} \mathrm{W}\right.$; Fig. 1). This long glacial fjord estuary was subject to glacial advancement and retreat over the past 250 years (Cooper 1937 , Hall et al. 1995), resulting in a large number of islands and reefs near the mouth. The largest concentrations of seals are found between May and August (Womble et al. 2010) in Johns Hopkins Inlet (JHI), a deep glacial inlet in the West Arm near the head of the bay that offers limited terrestrial haulout sites, and at the cluster of islands near the mouth of the bay, approximately $78 \mathrm{~km}$ from JHI. The Bay is subject to great tidal variation, at times exceeding a $6 \mathrm{~m}$ difference between high and low tide.

Seal capture and handling. We captured all seals using glacial habitat at JHI in the West Arm of Glacier Bay (Fig. 1). Seals using terrestrial haulouts were captured at Spider Reef Complex, Kidney Reef, Secret Bay, Geikie Rock, Leland Reef, Boulder Island, and a tidal passage near the mouth of the Bartlett River (Fig. 1).

Seals were captured in spring (14 April to 1 May) and fall (6 September to 7 October) in 2004 to 2006 using multifilament seine nets at terrestrial sites (Small et al. 2005) and monofilament gillnets at the glacial site. We live-captured a total of 146 harbor seals: 52 seals at terrestrial sites from 2004 to 2006 and 94 in the glacial habitat from 2005 to 2006.

Seals were transported to a research vessel where sex, weight to the nearest $0.1 \mathrm{~kg}$, and curvilinear body 


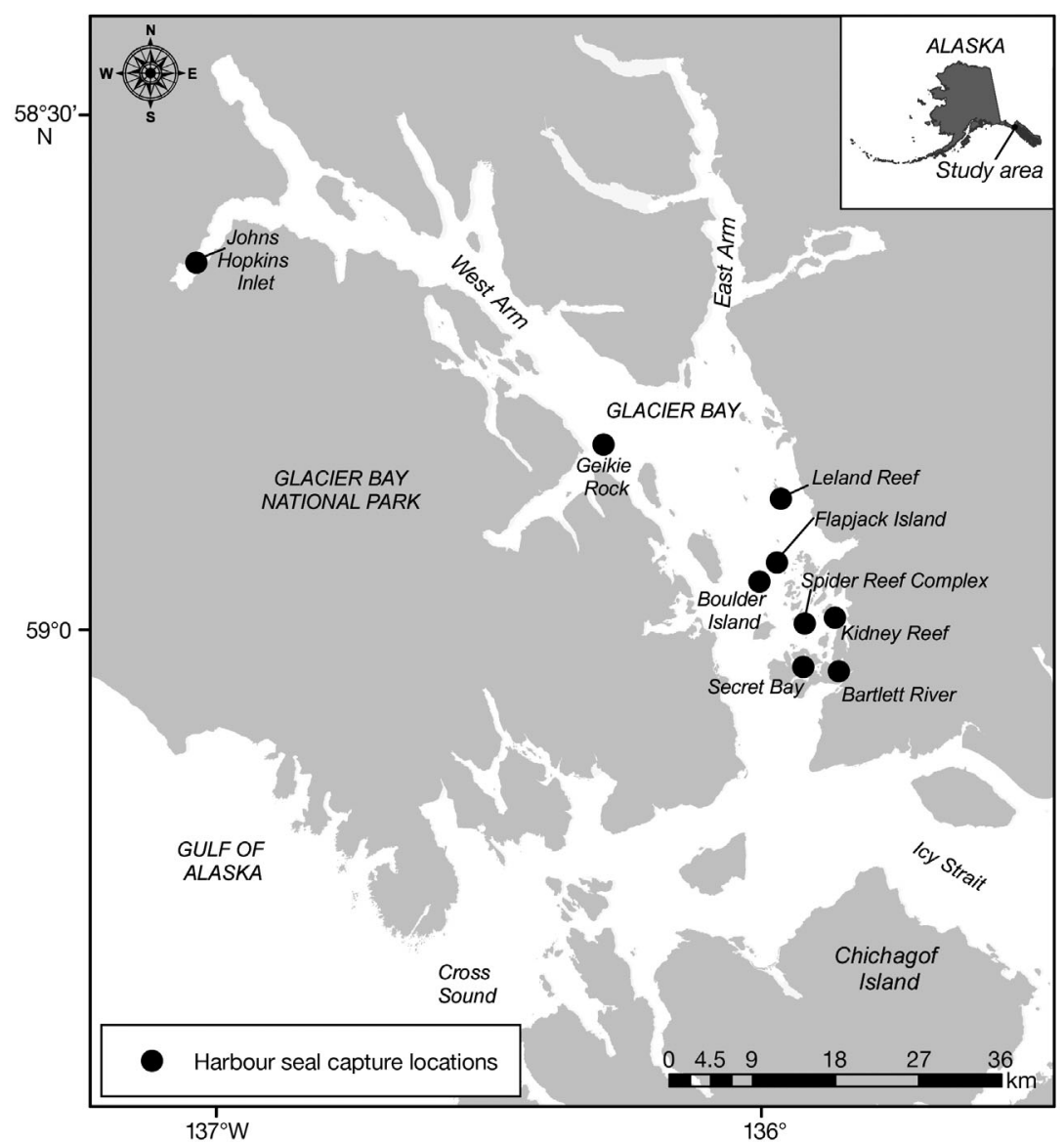

Fig. 1. Study area in Glacier Bay National Park, Alaska, USA. All glacial seals were captured in Johns Hopkins Inlet in the West Arm. Terrestrial seals were captured at all of the other capture locations indicated on the map later, after deuterium equilibrium had occurred.

We attached MM 340B very high frequency (VHF) headmounts (92 g, Advanced Telemetry Systems) to the pelage of a subset of seals $(n=70) ; 37$ of those seals also received MK-9 time-depth recorder tags (TDRs, Wildlife Computers). TDRs recorded depth every 2 s and conductivity (i.e. whether the instrument was wet, indicating that the animal was swimming, or dry, indicating the animal was hauled out) every $20 \mathrm{~s}$. TDRs were embedded in buoyant syntactic foam with a MM 230B backmount VHF transmitter (Advanced Telemetry Systems) to radio-track and retrieve TDRs shed during the annual molt. Flotation packages $(\sim 480 \mathrm{~g})$ had slight positive buoyancy and a sloped leading edge to reduce drag and were attached with $5 \mathrm{~min}$ epoxy to the pelage, lateral to the lumbar vertebrae. Pinnipeds experience seasonal changes in buoyancy due to changes in body composition (Pitcher 1986, Mellish et al. 2007); experimental manipulation of buoyancy simulating 12 to $26 \%$ subcutaneous fat did not alter diving metabolism (Fahlman et al. 2008). Thus, these relatively small ( $1 \%$ of body weight), slightly buoyant tags are not likely to negatively affect harbor seals.

Laboratory analysis. Blood was centrifuged at $1500 \times g$ for 10 min within 2 to $5 \mathrm{~h}$ of collection; blood cells and serum were length and axial girth to the nearest $1 \mathrm{~cm}$ were determined. Age of seals was determined morphometrically (Blundell \& Pendleton 2008); seals > 3 yr old were classified as adults, and seals $\leq 3 \mathrm{yr}$ of age were referred to as juveniles. Although some seals may not have reached sexual maturity by 3 yr of age (Harkonen \& Heide-Jorgensen 1990), they have achieved the majority of their body size and should be foraging in a manner similar to that of adults.

Seals were physically restrained to draw blood from their caudal epidural vein for stable isotope and body composition analyses. Following the initial blood draw, seals that were not pregnant were sedated with $0.25 \mathrm{mg} \mathrm{kg}^{-1}$ of diazepam administered intravenously. Pregnancy was determined by presence of a solid lump in an enlarged abdomen and, in some individuals, presence of a vaginal mucus plug. Following sedation, non-pregnant seals received an intramuscular injection of 0.4 to $0.6 \mathrm{~g} \mathrm{~kg}^{-1}$ deuterium oxide to estimate percent body fat based on total body water by hydrogen isotope dilution (Foy \& Schnieden 1960). A post-deuterium blood sample was collected $2.5 \mathrm{~h}$ separated and stored at $-18^{\circ} \mathrm{C}$ for up to 1 to $2 \mathrm{wk}$, then transferred to a $-80^{\circ} \mathrm{C}$ freezer until laboratory analysis occurred. We analyzed serum for stable isotope signatures ( $\mathrm{n}=135 ; 92$ glacial, 43 terrestrial seals) to indicate short-term diet (previous 2 to $3 w_{k}$ Lesage et al. 2002) in spring $(n=44)$ and fall $(n=91)$. We concentrated our dietary analyses on short-term diet because we assumed that what seals ate shortly before capture would be reasonably similar to what they ate in the short-term thereafter. We did not include nitrogen stable isotope signatures $\left(\delta^{15} \mathrm{~N}\right)$ in our interpretation of seal diets because previous studies demonstrated that carbon stable isotope signatures $\left(\delta^{13} \mathrm{C}\right)$ alone reliably distinguishes between the consumption of pelagic and intertidal/demersal fishes (Blundell et al. 2002, Herreman et al. 2009a). Laboratory methods used in our stable isotope analyses are reported in detail in Herreman et al. (2009a).

To assess body condition, we determined deuterium enrichment from paired (pre- and post-deuterium) samples of labeled water harvested from serum ( $\mathrm{n}=$ 292, representing 146 animals) using infrared spectrophotometry and a Thermo Mattson Satellite FT-IR 
(Fourier transform infrared) with a barium flouride $0.1 \mathrm{~mm}$ (Spectra-Tech) cell. (Farley \& Robbins 1994). Samples from seals captured in spring represent condition prior to pupping/breeding, while fall samples are from post-breeding individuals. To compensate for overestimation of total body water (TBW) when using deuterium oxide, we used the correction from Bowen \& Iverson (1998), TBW $=0.003+0.968 \times \mathrm{TBW}$. An equation to calculate percent body fat has not been developed specifically for harbor seals, so we used the equation from Reilly \& Fedak (1990) for grey seals Halichoerus grypus to determine percent total body fat (TBF) from TBW, $\mathrm{TBF} \%=105.1-1.47 \times \mathrm{TBW} \%$, $\mathrm{TBF} \%=$ percent total body fat.

Radio tracking and foraging locations. We documented presence/absence and the location of radiotagged seals using land-based data loggers (R4500S, Advanced Telemetry Systems) that continuously scanned $\left(20\right.$ s frequency $\left.^{-1}\right)$ for all VHF frequencies deployed. Two monitoring stations were established in 2004 at terrestrial haulouts and maintained through 2006. In 2005 and 2006 a third station monitored telemetry signals in JHI (the glacial site). In 2004, 2005, and 2006, from April through August, we had a total of 123,125 , and $155 \mathrm{~d}$, respectively, of telemetry monitoring at terrestrial sites. In 2005 and 2006 we monitored the glacial site for 50 and $116 \mathrm{~d}$, respectively.

To obtain focal observations of presumed foraging behavior on a subset of tagged seals we conducted boat-based VHF tracking. Vessel surveys occurred every other week for 4 to $5 \mathrm{~d}$ periods between late April and mid-August in 2004 ( $\mathrm{n}=26$ survey d), 2005 ( $\mathrm{n}=34$ survey d), and 2006 ( $\mathrm{n}=32$ survey d). A survey day consisted of 6 to $12 \mathrm{~h}$ of survey time between 7:00 and 20:00 h. VHF frequencies of tagged seals were scanned continuously while the vessel transited within detection range of all known haulout sites in the lower, mid, and upper West Arm of Glacier Bay (Fig. 1).

Seals were selected for tracking if they were at-sea, as determined by an intermittent VHF signal. When an at-sea signal was detected, 2 observers located the tagged seal on the surface of the water using highpower binoculars. Once the seal was located and confirmed by both observers, the date, time, and location (latitude and longitude) were recorded. Seals were presumed to be foraging if (1) an individual was followed for at least $1 \mathrm{~h}$, and (2) an individual dove repeatedly in the same general area. We obtained presumed foraging locations for 50 seals (31 females including 13 glacial seals and 19 males including 8 glacial seals). The location of each probable foraging area was imported into a GIS database. We measured the most direct swimming distance $(\mathrm{km})$ from the capture site to the presumed foraging area in ArcGIS (ESRI). This assumed that all foraging trips were initi- ated from the capture site, which was later confirmed by examining the fidelity of haulout locations.

Aircraft-based VHF tracking was conducted approximately every 7 to $10 \mathrm{~d}$ to assess habitat fidelity; however, aerial locations were not used to quantify distance to foraging sites because seal activity could not be determined. For adult females that were in lateterm pregnancy at the time of capture we determined the presence/absence of pups when individuals were sighted during pupping-season surveys. Of the 10 pregnant females whose TDRs were later recovered (6 in 2004, 2 in 2005, and 2 in 2006), 7 were visually observed and confirmed to have pups.

Habitat fidelity. To validate our comparison of activity budgets throughout the duration of instrument attachment as descriptive of behavior within a specific habitat, we designated seals as terrestrial or glacial based upon their capture site and assessed habitat fidelity using haulout locations from both transmitter types and all telemetry methods to assess habitat fidelity. TDRs were shed by 12 August, but head-mounted VHF tags often lasted through the end of August.

Signals from back-mounted VHF transmitters embedded with TDRs could only be heard consistently when seals were hauled out; thus, all TDR locations were used to assess habitat fidelity. Signals from headmounted VHFs were received when a seal was hauled out or in the water at the surface. Head-mount signals recorded by data loggers were used to assess habitat fidelity only if the signal was recorded on at least 2 consecutive scans within the same hour of a calendar day. When foraging or traveling, seals spend as little as 15 to $60 \mathrm{~s}$ on the surface (G. M. Blundell \& J. N. Womble pers. obs.); thus, in a sequential $20 \mathrm{~s}$ scan of each telemetry frequency ( $\geq 47$ frequencies), there was a low probability that the data logger would scan for a specific frequency twice in a row at the exact time that a diving or swimming seal was at the surface.

Data analyses. To examine patterns and estimate relationships for response variables of body condition, diet, foraging distance, and activity budget we used linear models for responses with one observation per seal (e.g.\% TBF, $\delta^{13} \mathrm{C}$ ), mixed linear models (Littell et al. 2006) for continuous responses with more than one observation per seal (e.g. trip duration), and mixed linear models (McCullagh \& Nelder 1989) for non-continuous responses (e.g. proportion of time dry) with multiple observations per seal (Table 1). For each analysis, we calculated a deviance-based analog of the $\mathrm{R}^{2}$ statistic $\left(R_{G}^{2}\right)^{1} \cdot R_{G}^{2}$ has the same interpretation as $R^{2}$ (i.e. the

\footnotetext{
1Ver Hoef JM (2003) From Galton to generalized linear models: the rise and fall of $\mathrm{R}_{\mathrm{G}}^{2}$ ? Unpublished report. National Marine Mammal Laboratory, National Marine Fisheries Service, Seattle, WA
} 


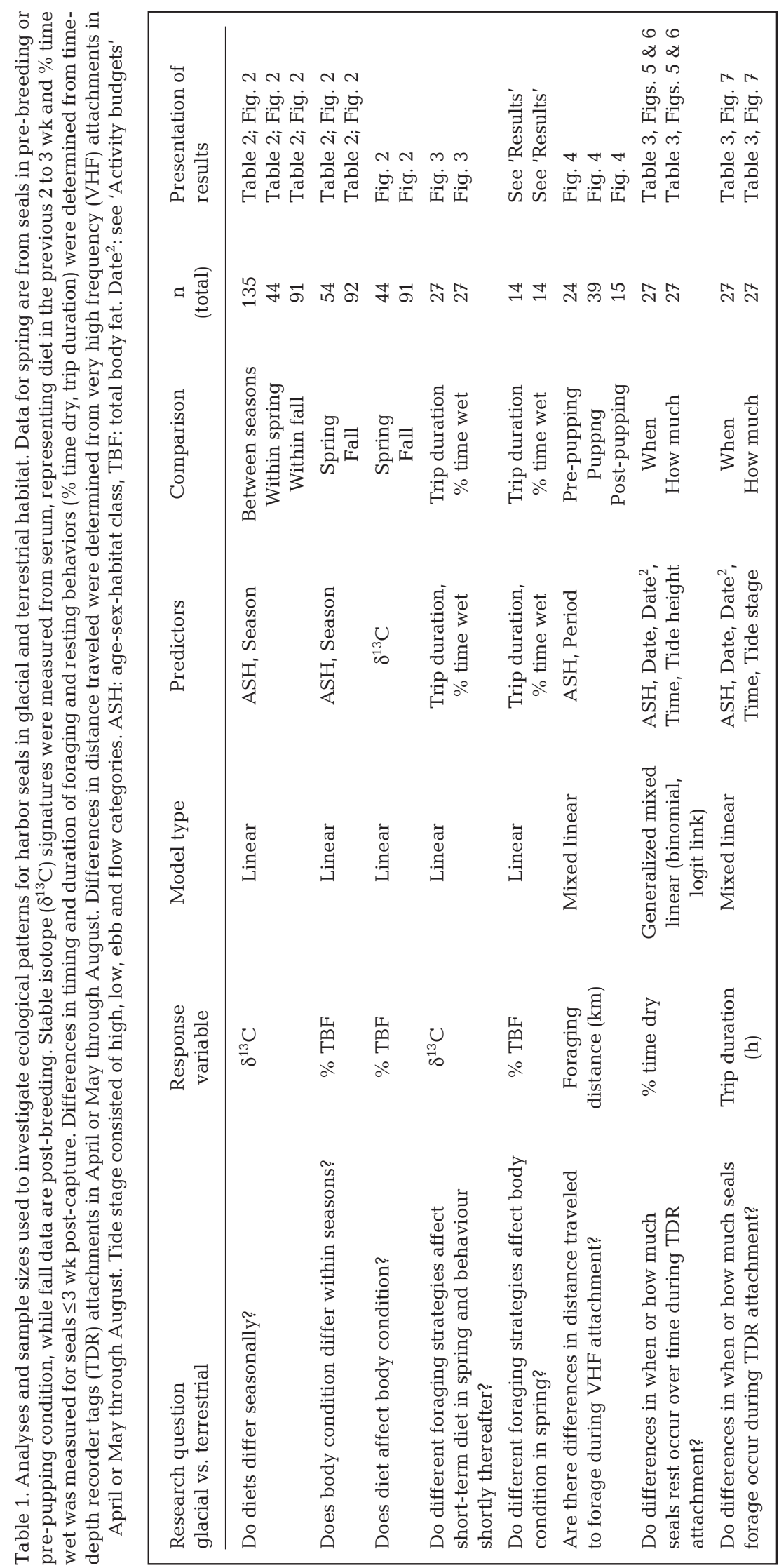

proportion of variation in the response variable that is accounted for by the model). Means, differences between means, and confidence intervals from these models were adjusted for other predictors included in the various models (i.e. SAS least-squares means; Littell et al. 2006). Because there were unequal samples among ages, sexes, and habitat classes, including some missing combinations and we therefore could not independently estimate the effects of these variables, we combined the 3 variables into a single age-sex-habitat (ASH) classification with a maximum of 8 levels.

Diet $\left(\delta^{13} \mathrm{C}\right)$ and body condition (\% TBF). For serum $\delta^{13} \mathrm{C}$ and percent TBF, we fit models with the predictors age, sex, and habitat and their 2-way interactions; the 3-way interaction could not be included due to missing age-sex groups. We also fit models separately for each season. We then estimated differences between means, or combinations of means to address specific questions (e.g. habitat or seasonal differences, Table 2), with the combinations appropriate to account for missing $\mathrm{ASH} \times$ Season combinations.

Although use of glacial habitat is seasonal for many seals, satellite telemetry data from harbor seals tagged in Glacier Bay indicate that seals generally begin returning to the area by early April (J. N. Womble unpubl. data); thus, data on short-term diet in spring likely characterizes prey obtained in Glacier Bay. Spring body condition may be more representative of where seals overwintered, which may not necessarily reflect effects of foraging in Glacier Bay. However, because some seals overwinter in Glacier Bay, we included spring data on body condition for comparison. Fall data (both diet and percent TBF) encompassed the season when harbor seals are present in the area in greater abundance and thus represented influences of foraging in Glacier Bay.

To assess the relationship between diet and foraging behavior, in separate analyses we estimated the relationships of serum $\delta^{13} \mathrm{C}$ and percent TBF with the predictors proportion of time 
Table 2. Phoca vitulina richardii. Mean differences in stable isotope signatures $\left(\delta^{13} \mathrm{C}\right)$ and \% total body fat (TBF) in harbor seals in Glacier Bay averaged across age-sex-habitat (ASH) groups (a) pooled from both seasons and (b) from each season separately.

\begin{tabular}{|c|c|c|c|c|c|c|c|}
\hline $\begin{array}{l}\text { Data } \\
\text { type }\end{array}$ & Season & Comparison & Mean & $\begin{array}{c}\text { Difference } \\
\text { in means }\end{array}$ & $\begin{array}{l}-95 \% \\
\text { Lower }\end{array}$ & $\begin{array}{l}\mathrm{CI}- \\
\text { Upper }\end{array}$ & $\mathrm{p}$ \\
\hline \multicolumn{8}{|c|}{ (a) Means pooled from both seasons } \\
\hline$\delta^{13} \mathrm{C}$ & Combined & $\begin{array}{l}\text { Spring } \\
\text { Fall }\end{array}$ & $\begin{array}{l}-16.35 \\
-17.29\end{array}$ & 0.94 & 0.68 & 1.19 & $<0.001$ \\
\hline$\delta^{13} \mathrm{C}$ & Combined & $\begin{array}{l}\text { Glacial } \\
\text { Terrestrial }\end{array}$ & $\begin{array}{l}-16.93 \\
-16.69\end{array}$ & 0.24 & -0.07 & 0.55 & 0.129 \\
\hline \multicolumn{8}{|c|}{ (b) Means from separate seasons } \\
\hline$\delta^{13} \mathrm{C}$ & Spring & $\begin{array}{l}\text { Glacial } \\
\text { Terrestrial }\end{array}$ & $\begin{array}{l}-16.75 \\
-16.28\end{array}$ & 0.47 & 0.01 & 0.94 & 0.047 \\
\hline$\% \mathrm{TBF}$ & Spring & $\begin{array}{l}\text { Glacial } \\
\text { Terrestrial }\end{array}$ & $\begin{array}{l}34.9 \\
38.2\end{array}$ & 3.3 & -0.5 & 7.0 & 0.085 \\
\hline$\delta^{13} \mathrm{C}$ & Fall & $\begin{array}{l}\text { Glacial } \\
\text { Terrestrial }\end{array}$ & $\begin{array}{l}-17.38 \\
-17.51\end{array}$ & -0.14 & -0.6 & 0.32 & 0.558 \\
\hline$\% \mathrm{TBF}$ & Fall & $\begin{array}{l}\text { Glacial } \\
\text { Terrestrial }\end{array}$ & $\begin{array}{l}33.8 \\
34.9\end{array}$ & 1.6 & -2.5 & 4.8 & 0.525 \\
\hline
\end{tabular}

many shorter ones). We related log trip duration to the predictors ASH and dayof-the-year (DOY). With the available data for this variable, we had $5 \mathrm{ASH}$ classes (Table 3). Also, we included a quadratic term for DOY to allow a nonlinear pattern in log trip duration over time and allowed the effect of DOY to vary by $\mathrm{ASH}$ (i.e. DOY $\times \mathrm{ASH}$ interactions). To account for potential correlations among repeated observations from the same seal, we included random effects (Littell et al. 2006) for individual seals and the interactions between the seal terms and the predictors (except $\mathrm{ASH}$ ); this is a random coefficient model that produces coefficient estimates averaged across seals with variances adjusted for among-seal patterns (Littell et al. 2006). We also included an autocorrelation term for within-seal correlation between temporally proximate observations.

in the water and mean trip duration from TDR data within 3 wk of capture.

Foraging distance. We transformed distance measurements (km traveled) from the VHF radio-tracking data collected in April and May through August using natural logarithms because the distribution of trip distances was highly skewed (i.e. many short trips, comparatively few long trips). Analyses using this transformation predict geometric mean responses, rather than arithmetic mean responses. The geometric mean is closer to the median and better represents the majority of the data for skewed distributions. We related log foraging distance with a categorical 'period' variable (pre-pupping, pupping, post-pupping), and because there were few observations per seal (range 1 to 6 , mean 2.2) and the majority of locations were well distributed through time, we did not include the withinseal correlation term.

Activity budgets. To investigate patterns in trip duration for each seal, we divided the total duration (h) from TDR data collected during April and May through midAugust into dry and wet intervals based on data from the wet-dry sensor. We defined an interval as dry if the wet-dry sensor measurement of conductivity was continuously $\geq 248$ and wet if conductivity was $<248$. This value was determined by examining graphs of TDR conductivity and depth measurements (corrected for surface error) to judge at what level seals appeared to be truly hauled out (i.e. dry). For analysis of trips we used all wet intervals > 30 min in duration. Data were transformed using natural logarithms because the distribution was highly skewed (i.e. few trips of very long duration and
To model the proportion of time dry (i.e. hauled out), we calculated the proportion of time dry for each hour for each seal throughout each TDR attachment. Using a generalized mixed linear model (binomial error distribution, logit link function) we related these proportions to the same predictor variables as used in the analyses of log trip duration as well as tide height, tide category (high, low, flood/rising, or ebb/falling), timeof-day, and interactions of $\mathrm{ASH}$ with tide and time. Either tide height or tide category, but not both, were included in a single model. Time was broken into eight $3 \mathrm{~h}$ blocks, midnight to 03:00 h, 03:00 to 06:00 h, etc. This model also included the same random and autocorrelation effects as the trip duration analysis.

Table 3. Phoca vitulina richardii. Mean ( $\pm 95 \%$ confidence intervals) proportion of time dry and geometric mean trip durations through time from time-depth recorder tag (TDR) data (April/May to August) by age-sex-habitat (ASH) classes. Estimated means are adjusted for other predictors in the model. Means not followed by the same letter are statistically different. AFG: adult female glacial; JFG: juvenile female glacial; AFT: adult female terrestrial; JFT: juvenile female terrestrial; AMT: adult male terrestrial. ${ }^{*} \mathrm{p}<0.05$ for dry time, ${ }^{* *} \mathrm{p}<0.01$ for trip duration

\begin{tabular}{|lccl|}
\hline ASH & $\mathrm{n}$ & Proportion of time dry & Trip duration (h) \\
\hline AFG & 2 & $0.26(0.10,0.53)^{\mathrm{a}}$ & $2.54(1.40,4.61)^{\mathrm{a}}$ \\
JFG & 6 & $0.26(0.15,0.40)^{\mathrm{a}}$ & $4.07(2.81,5.88)^{\mathrm{a}, \mathrm{b}}$ \\
AFT & 11 & $0.15(0.10,0.23)^{\mathrm{b}}$ & $3.56(2.76,4.60)^{\mathrm{a}, \mathrm{b}}$ \\
JFT & 3 & $0.16(0.07,0.32)^{\mathrm{a}, \mathrm{b}}$ & $4.99(3.04,8.18)^{\mathrm{b}, \mathrm{c}}$ \\
AMT & 5 & $0.11(0.06,0.21)^{\mathrm{b}}$ & $6.33(4.34,9.24)^{\mathrm{c}}$ \\
\hline
\end{tabular}




\section{RESULTS}

\section{Habitat fidelity}

Telemetry-relocation data indicated that seals exhibited high fidelity to the habitats in which they were initially captured. For seals from which we recovered TDRs ( $\mathrm{n}=8$ glacial seals, $\mathrm{n}=19$ terrestrial seals; Appendix 1), the average number of days seals were located with telemetry (i.e. at least one location in a calendar day including foraging locations) was $31.3 \pm$ $21.3 \mathrm{~d}$ (mean $\pm \mathrm{SD}$ ) . The average number of days that seals were at haulout locations was $29.6 \pm 21.5 \mathrm{~d}$ ind. $^{-1}$ (Appendix 1). All but 3 of the TDR-equipped seals had haulout locations entirely in the habitats in which they were originally captured. One of those 3 (04GB16) was pregnant when captured in a terrestrial habitat and had $96 \%$ of her haulout locations in terrestrial habitat (Appendix 1) but was located on 4 June and 18 June in glacial habitat with a pup. The other 2 seals, both juvenile glacial females, spent most of their time away from the habitat in which they were captured (Appendix 1). Our larger sample of seals with head-mounted transmitters, including 21 glacial seals, also showed that glacial-captured seals had a $97 \%$ fidelity to glacial habitat.

The high degree of fidelity of radio-tagged seals clearly demonstrates that seals generally returned to a specific habitat to rest when they were not foraging. This high habitat fidelity validates our data comparisons (e.g. TDR-derived activity budgets, diet and body condition for radio-tagged and untagged seals) as being representative of glacial or terrestrial seals in Glacier Bay.

\section{Diet and body condition}

The variation among group means $(\mathrm{ASH} \times$ Season) for both $\delta^{13} \mathrm{C}$ and percent TBF was greater in the fall than in the spring (Fig. 2). On average, diets of fallcaptured seals had more pelagic fishes (i.e. lower $\delta^{13} \mathrm{C}$ values) than in spring; this pattern was consistent for all ASH groups except for terrestrial adult females, whose diet grouped with that of spring-captured seals (Fig. 2). Glacial seals, on average, tended to have diets with more pelagic fishes than terrestrial seals (Fig. 2), but the pattern was not consistent among all groups (e.g. fall-captured juvenile terrestrial females).

Pelagic fishes, particularly before spawning (i.e. during spring and early summer), are higher in lipids and energy density than are intertidal/demersal fishes with higher $\delta^{13} \mathrm{C}$ values (Anthony et al. 2000). Although not evident in spring, in fall (Fig. 2a), there was a general relationship of increasing percent TBF with decreasing

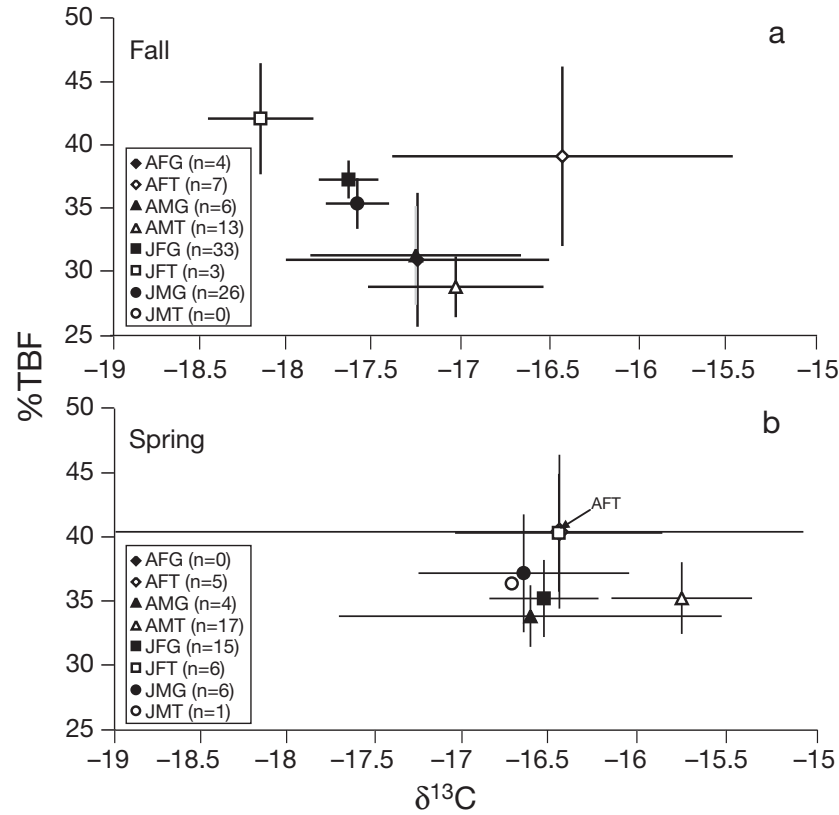

Fig. 2. Phoca vitulina richardii. Mean values (95\% CI) serum $\delta^{13} \mathrm{C}$ and $\%$ total body fat (TBF) for age-sex-habitat (ASH) groups in each season (spring and fall). Solid symbols: glacial seals; open symbols: terrestrial seals. A: adult ( $>3 \mathrm{yr})$; J: juvenile (pups and seals $\leq 3 \mathrm{yr}$ ); F: females; M: male; G: captured in glacial habitat; $\mathrm{T}$ : captured in terrestrial habitat. Seals in the fall in both habitats had diets higher in pelagic fishes than seals during the spring $(\mathrm{p}<0.001)$; however, ATF were grouped with spring-captured seals, i.e. had a diet of intertidal/demersal fishes. Body condition of fall-captured AFG, AMG and AMT was lower than that of other ASH groups. Serum $\delta^{13} \mathrm{C}$ ASH $\times$ Season model: deviance-based analog $\left(\mathrm{R}_{\mathrm{G}}^{2}\right)=0.29 ; \% \mathrm{TBF}$ ASH $\times$ Season model: $\mathrm{R}_{\mathrm{G}}^{2}=0.54$. Longest horizontal line $=$ AFT error bar

$\delta^{13} C_{i}$ however there were age and habitat effects within this pattern, likely as a result of post-reproductive condition of adults in the fall. The mean percent TBF for glacial adult females in the fall was very low relative to the means for other female groups (Fig. 2a), especially that for terrestrial adult females in both seasons. We have no percent TBF data from glacial adult females in the spring for comparison because pregnant seals were not detained for the lengthy post-deuterium sampling process. Adult males, especially terrestrial seals, were fatter in the spring than in the fall (Fig. 2).

The means presented above are marginal means (i.e. SAS least squares; Littell et al. 2006) averaged across ASH groups; thus, the estimates and associated statistics are adjusted for other variables in the model. We also compared glacial and terrestrial seals by analyzing each season and each variable separately, including ASH group in the model. In spring, glacial seals had diets significantly higher in pelagic fishes, but TBF did not differ from terrestrial seals in spring (Table 2). In the fall, diet was more variable than in spring. Again, glacial seals tended to have diets higher in 
pelagic fishes (Fig. 2b), but as a result of the pelagic diet of juvenile terrestrial females $(n=3)$, diets averaged across ASH groups did not differ between habitats (Table 2). Body condition averaged across ASH groups also did not differ between habitats.

Based on data from within 3 wk of spring captures, short-term diet was positively related to mean trip duration $(p=0.06)$; those seals with shorter trips (Fig. 3a) tended to have lower $\delta^{13} \mathrm{C}$ signatures (i.e. pelagic diets). That seals with more pelagic fish in their diet had shorter trips is especially evident for some terrestrial seals. Trip length was less of a factor for glacial seals because all trips were mid-length and diets were predominantly pelagic. There was no relationship between proportion of time wet and diet $(p=0.382$; $\mathrm{R}_{\mathrm{G}}^{2}=0.21$; Fig. 3b). Percent TBF, although not statisti-
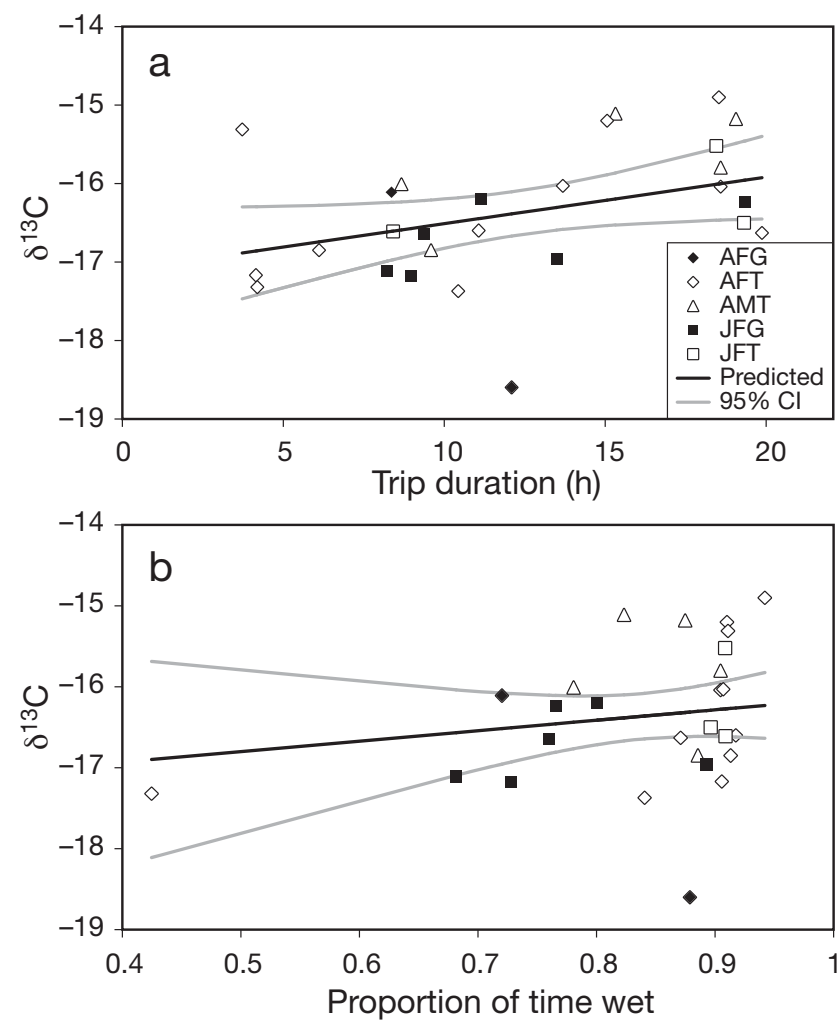

Fig. 3. Phoca vitulina richardii. Short-term diet indices. $\delta^{13} \mathrm{C}$ in serum was positively related to (a) mean trip duration $(\mathrm{p}=$ 0.062 ) but not significantly related to (b) proportion of time wet $(\mathrm{p}=0.382)$ during the $3 \mathrm{wk}$ following capture, $\delta^{13} \mathrm{C}=-18.19+$ $1.29 \times$ proportion time wet $+0.059 \times$ trip duration; deviancebased analog $\left(\mathrm{R}_{\mathrm{G}}^{2}\right)=0.21$. The graph for each predictor is plotted as the effect of that predictor on the response at the mean value of the other predictor (e.g. the effect of mean trip duration on short-term diet is plotted at the mean value of proportion of time wet for each age-sex-habitat [ASH] group). Lower $\delta^{13} \mathrm{C}$ values indicate a diet of pelagic fishes. Diversity of diet was more pronounced for terrestrial seals; thus, the diet vs. trip duration had a stronger relationship for terrestrial seals than for glacial seals that have more similar (primarily pelagic) diets. See Fig. 2 for ASH class abbreviations cally significant, was negatively related to mean trip duration within $3 \mathrm{wk}$ of capture $(\mathrm{p}=0.079)$ but was unrelated to proportion of time wet $\left(\mathrm{p}=0.823 ; \mathrm{R}_{\mathrm{G}}^{2}=\right.$ 0.22). We do not have telemetry data for fall-captured seals; thus, we cannot evaluate diet or body condition relative to foraging behavior.

Fig. 3 also provides a visual comparison of trip duration and proportion of time wet for seals in each habitat prior to pupping or mating, when adult and juvenile behavior will differ. Terrestrial seals had trips of varying lengths but collectively spent a greater proportion of their time wet. In contrast, all but one glacial seal consistently had trips that were approximately $10 \mathrm{~h}$ in length (Fig. 3a) but spent a smaller proportion of their time in the water (Fig. 3b) than did terrestrial seals.

\section{Foraging distance}

Geometric mean foraging distances were uniformly small $(<5 \mathrm{~km})$ for terrestrial seals in all 3 periods (Fig. 4). In the pupping period, glacial adults had much longer geometric mean foraging distances than did corresponding terrestrial adults $(\geq 40$ vs. $<4 \mathrm{~km}$; females, $p=0.014$; males, $p=0.006)$. We had only one

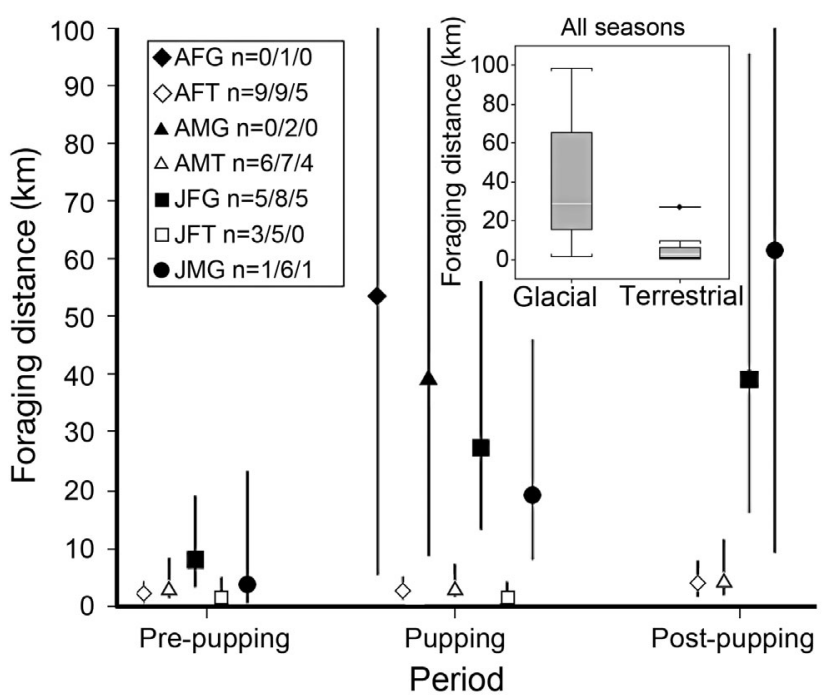

Fig. 4. Phoca vitulina richardii. Seasonal geometric mean (95\% CI) distance $(\mathrm{km})$ between foraging location and capture site for seals with very high frequency (VHF) headmounted tags that were captured in glacial and terrestrial habitats and subsequently radio tracked during spring and summer in Glacier Bay. Sample sizes for each age-sex-habitat (ASH) group in the key denote number of seals with foraging locations during pre-pupping, pupping, post-pupping seasons, respectively. Upper limits of confidence intervals that reach 100 on the graph actually extend beyond 100. Foraging distance $\mathrm{ASH} \times$ Period model: deviance-based analog $\left(\mathrm{R}_{\mathrm{G}}{ }_{\mathrm{G}}\right)=$ 0.42. Inset: whiskers are minimum and maximum; box defines 1st and 3rd quartile; white line is median. See Fig. 2 for ASH abbreviations 
location during pupping season for a parturient adult glacial seal, which was a long-distance foraging location on the last day of our pre-defined pupping season when her pup likely was already weaned. Geometric mean foraging distances for glacial juveniles increased over time (pre-pupping vs. post-pupping: females, $\mathrm{p}=$ 0.003; males, $\mathrm{p}=0.030$ ).

\section{Activity budgets}

Of the 27 seals from which TDRs were recovered, 2 adult females captured in glacial habitat were in lateterm pregnancy, as were 8 seals captured at terrestrial sites (Appendix 1). In the analysis of the proportion of time dry, glacial seals - both juvenile and adult females - had no or weak relationships between proportion of time dry and tide height ( $p>0.220 ;$ Fig. 5). In contrast, all age/sex cohorts of terrestrial seals had a negative relationship between proportion of time dry and tide height ( $p<0.049)$, hauling out much more when tides were low compared to when tides were high (Fig. 5). Terrestrial seals also spent a greater proportion of time hauled out when the tide was falling than when rising $(p<0.001)$; however, the proportion of time hauled out at low tide exceeded that of all other tide categories by $>0.10$ for all age/sex categories. There was no relationship between proportion of time hauled out and tide category for glacial seals ( $p>0.350)$.

When accounting for other factors in the models, the mean proportion of time dry was highest for females using glacial ice (both adult and juvenile), lowest for adult males using terrestrial sites, and intermediate for females in terrestrial habitat, although proportion of time dry for terrestrial juveniles was not statistically

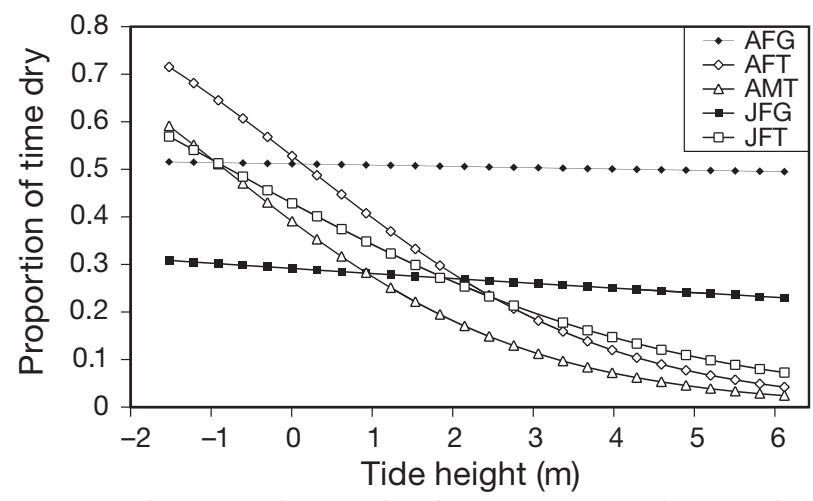

Fig. 5. Phoca vitulina richardii. Proportion of time dry (hauled out) relative to tide height for seals equipped with time-depth recorder tags (TDRs). Tide height had no effect on when seals hauled out in the glacial habitat ( $p>$ 0.220 ) but tide did have an effect when terrestrial seals hauled out ( $\mathrm{p}<0.049$ ), which occurred during low tides. See Fig. 2 for age-sex-habitat (ASH) abbreviations. Sample sizes as in Table 3 different than that of glacial females (Table 3). All ASH groups had variable patterns of proportion of time dry across time $(p<0.002)$. Adult females from the glacial habitat had the most distinctive pattern with a high proportion of time dry and a strong peak in the middle of the pupping period (Fig. 6). Adult females from terrestrial sites had lower overall levels and a much weaker peak, late in the pupping period (Fig. 6). Juvenile females had a strong increasing proportion of time dry over time, and adult males had the lowest proportion of time dry, showing some increase over time (Fig. 6). No pronounced trends were evident in proportion of time dry relative to time of day.

In the analyses of trip duration, most predicted geometric mean durations were $<10 \mathrm{~h}\left(\mathrm{R}_{\mathrm{G}}^{2}=0.085\right.$; Fig. 7). Only glacial adult females had variable patterns in mean trip duration over time $(p=0.035)$. Mean trip duration for other ASH groups did not differ across time from constant $(p>0.18)$. Glacial adult females, which were pregnant at the time of capture, had notably shorter trips during pupping season than did all other ASH groups (Fig. 7). In contrast, terrestrial adult females, $73 \%$ of which were pregnant at capture (Appendix 1), showed little change in trip duration during pupping. Glacial adult females also tended to spend more time in the water, presumably foraging, before and after pupping season than did terrestrial adult females or other ASH groups (except adult terrestrial males). When accounting for the other factors in the models, the geometric mean trip duration from spring tagging until August molt was highest for adult males, lowest for adult females from both habitats, and intermediate for juvenile females (Table 3).

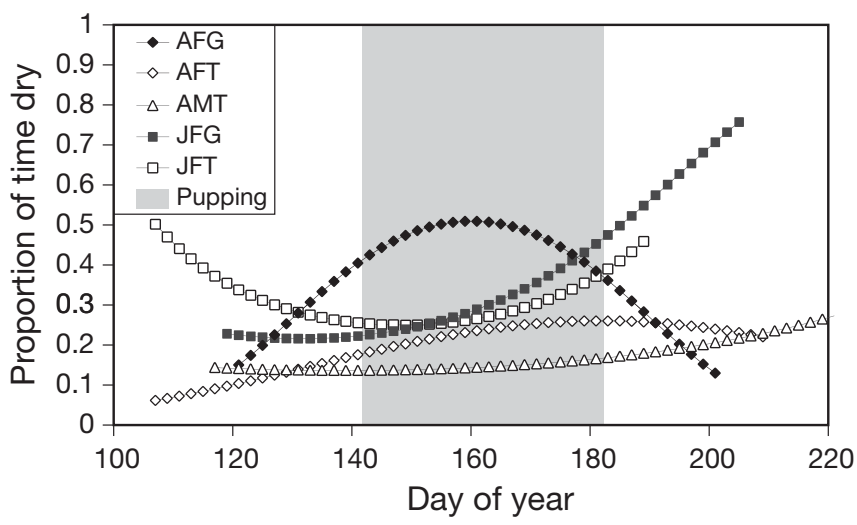

Fig. 6. Phoca vitulina richardii. Proportion of time dry relative to day of the year for seals equipped with time-depth recorder tags (TDRs). Pupping season lasted from 22 May through 1 July (shading). All age-sex-habitat (ASH) groups had variable patterns of proportion of time dry across time $(p<0.002)$, but glacial seals that were pregnant at the time of capture had the most distinctive pattern, spending more time hauled out during pupping season than did pregnant females at terrestrial sites. See Fig. 2 for ASH abbreviations. Sample sizes as in Table 3 


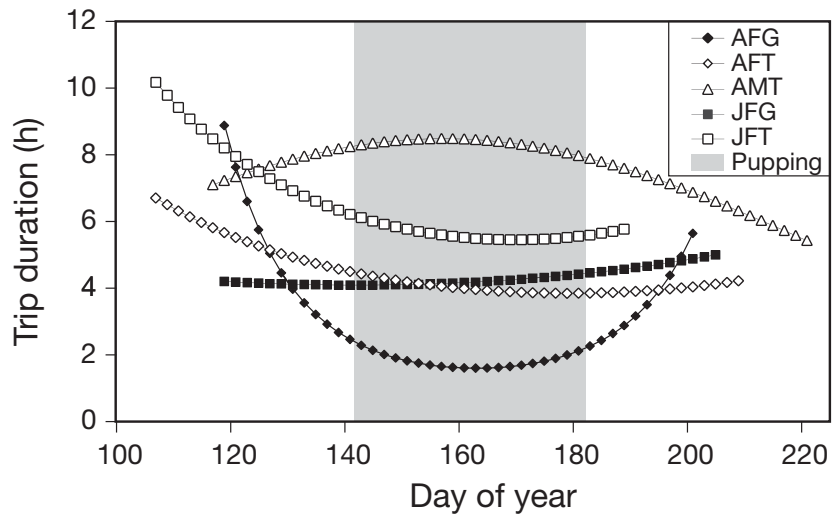

Fig. 7. Phoca vitulina richardii. Predicted geometric mean trip duration of trips for different days of the year during spring and summer (deviance-based analog $\left[\mathrm{R}_{\mathrm{G}}^{2}\right]=0.085$ ) for seals equipped with time-depth recorder tags (TDRs). Pupping season lasted from 22 May through 1 July (shading). Only glacial adult females had variable patterns in mean trip durations over time $(p=0.035)$. Mean trip durations for other age-sex-habitat (ASH) groups did not differ across time from constant $(p>0.18)$. Adult females in glacial ice that were pregnant at the time of capture tended to spend more time in the water before and after pupping season than did other ASH groups, but trips were notably shorter in duration than were those of other seals during pupping season. See Fig. 2 for ASH abbreviations

\section{DISCUSSION}

Our study provides evidence that harbor seals that use glacial ice have markedly different foraging strategies and activity budgets compared to seals that use terrestrial haulouts. The similarity in body condition of all seals (juveniles and adults) regardless of habitat, suggests that the energetic cost to glacial seals of traveling farther to forage is offset by spending more time resting and, for the most part, obtaining a higher quality pelagic diet (Anthony et al. 2000). Further, our data support the hypothesis that accessibility of haulout substrate, independent of tides, may be a major benefit for seals using glacial habitat (Calambokidis et al. 1987).

The discovery that most glacial seals travel farther to forage than their terrestrial counterparts was unexpected and suggests that seals are not using ice substrate because of its proximity to prey resources. Glacial seals timed foraging to coincide with nocturnal, near-surface availability of pelagic fishes (Krutzikowsky \& Emmett 2005, Hagan \& Able 2008); however, when tides were conducive, the same could be said for seals in terrestrial habitat. Glacial seals also did not time their departure and return from long foraging trips to take advantage of directional currents associated with tides. Haulout times were centered around midday, when solar heat peaks.

Glacial seals may have become satiated more rapidly when foraging on schooling pelagic fishes than if for- aging on the non-schooling intertidal/demersal prey consumed by terrestrial seals, enabling glacial seals to return and haul out on consistently available ice. In contrast, all terrestrial seals but one spent a greater proportion of their time in the water than did glacial seals, perhaps because high tides prevented terrestrial seals from hauling out once satiated.

The post-spawning lipid content of pelagic fishes is diminished (Anthony et al. 2000) and the energy density of some pelagic species is not substantially different from many intertidal/demersal fishes. Pelagic fishes, such as Pacific herring Clupea pallasii, capelin Mallotus villosus, Pacific sandlance Ammodytes hexapterus and eulachon Thaleichthys pacificus, may spawn in Alaska from March through August. The exact timing of spawning in Glacier Bay is not well established for most species (Robards et al. 2003, Arimitsu et al. 2008), but capelin have been observed spawning in Glacier Bay during June and July (Robards et al. 2003).

Thus, during spring through at least part of the summer, the combination of a better diet and more time hauled out appears to result in net energy expenditures for glacial seals that are similar to those of terrestrial seals. Dietary differences between habitats became less pronounced as differences in prey quality diminished, or pelagic prey became less available to seals as a result of increased competition from other piscivorous predators that seasonally use the area (Herreman et al. 2009a). Although body condition averaged across cohorts did not differ between habitats in the fall, the costs of energy-use strategies employed by specific age-sex cohorts manifested themselves differently for seals in each habitat.

The diet and condition data for our larger sample of fall-captured seals are consistent with what would be expected as a result of the diet and activity budgets noted for our spring-captured seals. Of the adult females that we captured in the spring in both habitats (including seals without telemetry transmitters), $87 \%$ were pregnant, so the majority of adult females that we captured in the fall likely had pupped that year. The finding that adult terrestrial females captured in the fall had higher body fat than all but juvenile terrestrial females suggests that adult females likely conserved some body fat during lactation by successfully foraging on nearby intertidal/demersal fishes. Despite potentially having spent more time foraging before and after pupping season, parturient glacial seals may have substantially depleted body fat during lactation by spending more time hauled out with their pups and less time foraging and thus had not recovered by the fall to a level comparable to their terrestrial counterparts. The low body fat of glacial adult females in the fall was rivaled only by that of adult males from both habitats. 
Males engaged in breeding displays or patrolling spend minimal time foraging during pupping and mating season (Walker \& Bowen 1993, Boness et al. 2006), a behavior that appears evident from activity budgets of our spring-captured terrestrial males. Our data indicate that there are costs and benefits to using glacial habitat that may result in complicated energy balances, particularly for reproductively active seals.

As long as tidewater glaciers are actively calving reasonably flat ice, $>1 \mathrm{~m}$ in diameter (Hoover 1983), during the pupping, mating, and molting seasons, more surface area is available for seals to haul out on compared with most terrestrial sites, especially at high tides. Other advantages to hauling out individually or in smaller groups on individual icebergs may exist, such as a reduction in intraspecific aggression or disease transmission (Hoover 1983). Glacial seals would only need to travel until sufficient prey are encountered and captured and their energetic needs are met, after which - regardless of tides - they can return to haulout and rest on floating substrate, ceasing energy expenditure for travel, absorbing solar radiation, and minimizing vigilance for predators.

Without survival data, we cannot assess whether predation is reduced at glacial sites. Such an assumption seems reasonable when seals are hauled out on icebergs, as they would be inaccessible to most terrestrial predators and may be difficult to locate for aquatic predators amongst densely packed icebergs. Conversely, when glacial seals engage in extended foraging trips, their exposure to aquatic predators is likely more prolonged than that of their terrestrial counterparts that can remain in shallow water, vigilant for predators, when they are not foraging and their terrestrial haulouts are submerged. Thus, the use of glacial habitat would not appear to be exclusively a predatoravoidance strategy, except when seals are resting and perhaps during pupping season.

Our 2 pregnant glacial females spent on average $<2 \mathrm{~h}$ trip $^{-1}$ in the water during pupping season in contrast to the longer trips of adult terrestrial females $(\sim 4 \mathrm{~h}$ trip $^{-1}$ ) and all other ASH groups, indicating that these glacial females likely kept their pups within the confines of glacial ice in the long glacial inlet. Remaining within icebergs potentially decreases a pup's exposure to predators and may enhance its probability of survival to weaning. Further, if a greater proportion of time hauled out in glacial habitat translates into more time spent nursing, glacial-born pups could potentially wean at higher weights than terrestrial-born pups, which may increase their survival through the first year (Harding et al. 2005). More time spent nursing and resting may also allow pups to grow faster and wean sooner, giving them more time to learn to forage before winter. Indeed, Hoover (1983) noted that glacial-born pups had among the shortest weaning times reported for harbor seals. Although our data are insufficient to evaluate potential fitness benefits to the use of glacial habitat, our results suggest an advantage and can guide study designs for future research.

Given that many seals appear to travel from other locations to pup on glacial ice (Calambokidis et al. 1987, Herreman et al. 2009b), just how far-reaching and serious will the impacts of loss of glacial habitat be? Our study, along with another on the winter movements of harbor seals tagged in glacial ice (Womble et al. 2010), documented high fidelity to glacial habitat, which may indicate that suitable pupping habitat at terrestrial sites is limited. As glacial habitat is reduced, will harbor seals accustomed to pupping on ice switch to terrestrial habitats and successfully rear pups? Some juveniles in this study showed less fidelity to habitat, did not conform to the diets generally consumed by older seals, and traveled farther to forage as time went on, suggesting that juveniles have the highest potential for adapting to the loss of glacial habitat by foraging on different prey and finding new habitat. Indeed, in many species, juveniles are the most likely individuals to disperse (Knowlton \& Graham 2010). Perhaps the continued decline in seal numbers at Glacier Bay despite high pup production (Mathews \& Pendleton 2006, Womble et al. 2010) is an indication that juvenile dispersal is prevalent and the majority of juveniles do not return to their natal habitat to reproduce.

Ringed seals Phoca hispida and bearded seals Erignathus barbatus are 2 Arctic pinnipeds that are predicted to be the least sensitive to climate-induced changes in sea ice due to their broad geographic distribution, large populations, and flexible use of habitat (Laidre et al. 2008); however, ringed seals may be particularly vulnerable during pupping (Kovacs \& Lydersen 2008, studies reviewed in Laidre et al. 2008). Predictions of the effects of climate change on Arctic species are largely speculative, however, and are based on few baseline and long-term data sets (Laidre et al. 2008). Other important factors or indirect effects that have yet to be considered are possible (Bluhm \& Gradinger 2008, Laidre et al. 2008). Similarly, our study revealed marked differences between glacial and terrestrial seals but raised additional questions that need to be answered to better understand the importance of glacial habitat to harbor seals in Alaska, how well they may adapt to loss of that habitat, and the geographic extent of possible effects of habitat loss. Given the similarity of harbor seals to Arctic seals in many respects, especially to the closely related spotted seal Phoca largha (Shaughnessy \& Fay 1977), the more easily studied harbor seals have high potential to serve as an indicator species to predict effects of climate change on ice-associated pinnipeds. 
If Alaskan glaciers continue to recede and rapidly melt (Arendt et al. 2002, Molnia 2007), the energetic balance of harbor seals may change as more tidewater glaciers ground and no longer calve icebergs, leaving harbor seals in Alaska with fewer options for hauling out. The consequences may be especially pronounced for harbor seals that seasonally use this habitat for pupping and breeding if the large numbers of pups born in glacial habitat (Womble et al. 2010, Mathews \& Pendleton 2006) recruit to areas well beyond the inlets in which they are born, effectively functioning as emigrants from a source population. Additional studies with increased sample sizes of radio-tagged harbor seals are needed at other glacial sites to document movements, foraging strategies, and (to the extent possible) fitness, to facilitate predictions of population-level and regional consequences as ice becomes less available to seals as a result of climate change in Alaska.

Acknowledgements. We thank the many individuals from the Alaska Department of Fish and Game (ADF\&G), the National Marine Fisheries Service (NMFS)/National Marine Mammal Laboratory, the National Park Service, the Alaska SeaLife Center, and the students from various universities who assisted with the capture and tagging of harbor seals. We also thank the captain and crew of the MV 'Steller' and the staff of Glacier Bay National Park, particularly J. Smith, B. Eichenlaub, S. Boudreau, T. Lee, and the Hoonah Indian Association for support of this study. J. Norvell (Tal Air) aided in TDR retrieval. We appreciate constructive comments provided on earlier drafts by A. Hoover-Miller, L. Quakenbush and 3 anonymous reviewers. Research was conducted under NMFS Research Permits \#3581585 and \#358-1787, Glacier Bay National Park and Preserve Permit No. GLBA-2004-SCI-0013, and an ADF\&G Animal Care and Use Committee permit. ADF\&G was funded for capture, tagging, and sampling of seals by congressional appropriations administered through NMFS, tracking of foraging seals was funded by the National Park Service Coastal Program, a grant from the National Park Foundation, Ocean Alaska Science \& Learning Center, and the NMFS-Alaska Fisheries Science Center-Auke Bay Laboratory.

\section{LITERATURE CITED}

Anthony JA, Roby DD, Turco KR (2000) Lipid content and energy density of forage fishes from the northern Gulf of Alaska. J Exp Mar Biol Ecol 248:53-78

Arendt AA, Echelmeyer KA, Harrison WD, Lingle CS, Valentine VB (2002) Rapid wastage of Alaska glaciers and their contribution to rising sea level. Science 297:382-386

Arimitsu ML, Piatt JF, Litzow MA, Abookire AA, Romano MD, Robards MD (2008) Distribution and spawning dynamics of capelin (Mallotus villosus) in Glacier Bay, Alaska: a cold water refugium. Fish Oceanogr 17:137-146

Bengston JL, Phillips AV, Mathews EA, Simpkins MA (2007) Comparison of survey methods for estimating abundance of harbor seals (Phoca vitulina) in glacial fjords. Fish Bull 105:348-355

Bluhm BA, Gradinger R (2008) Regional variability in food availability for Arctic marine mammals. Ecol Appl 18: S77-S96
Blundell GM, Pendleton GW (2008) Estimating age of harbor seals (Phoca vitulina) with incisor teeth and morphometrics. Mar Mamm Sci 24:577-590

Blundell GM, Ben-David M, Bowyer RT (2002) Sociality in river otters: cooperative foraging or reproductive strategies? Behav Ecol 13:134-141

Boness DJ, Bowen WD, Oftedal OT (1994) Evidence of a maternal foraging cycle resembling that of otariid seals in a small phocid, the harbor seal. Behav Ecol Sociobiol 34:95-104

Boness DJ, Bowen WD, Buhleier BM, Marshall GJ (2006) Mating tactics and mating system of an aquatic-mating pinniped: the harbor seal, Phoca vitulina. Behav Ecol Sociobiol 61:119-130

Bowen WD, Iverson SJ (1998) Estimation of total body water in pinnipeds using hydrogen-isotope dilution. Physiol Zool 71:329-332

Bowen WD, Iverson SJ, Boness DJ, Oftedal OT (2001) Foraging effort, food intake and lactation performance depend on maternal mass in a small phocid seal. Funct Ecol 15: 325-334

Boyd IL, Murray AWA (2001) Monitoring a marine ecosystem using responses of upper trophic level predators. J Anim Ecol 70:747-760

Calambokidis J, Taylor BL, Carter SD, Steiger GH, Dawson PK, Antrim LD (1987) Distribution and haul-out behavior of harbor seals in Glacier Bay, Alaska. Can J Zool 65:1391-1396

> Cooper WS (1937) The problem of Glacier Bay, Alaska: a study of glacier variations. Geogr Rev 27:37-62

> Fahlman A, Hastie GD, Rosen DAS, Naito Y, Trites AW (2008) Buoyancy does not affect diving metabolism during shallow dives in Steller sea lions Eumatopias jubatus. Aquat Biol 3:147-154

Farley SD, Robbins CT (1994) Development of two methods to estimate body composition of bears. Can J Zool 72: $220-226$

Foy JM, Schnieden H (1960) Estimation of total body water (virtual tritium space) in the rat, cat, rabbit, guinea-pig, and man, and of the biological half-life of tritium in man. J Physiol 154:169-176

Hagan SM, Able KW (2008) Diel variation in pelagic fish assemblage in a temperate estuary. Estuar Coast 31:33-42

Hall DK, Benson CS, Field WO (1995) Changes of glaciers in Glacier Bay, Alaska, using ground and satellite measurements. Phys Geogr 16:27-41

> Harding KC, Fujiwara M, Axberg Y, Harokonen T (2005) Mass-dependent energetics and survival in harbour seal pups. Funct Ecol 19:129-135

Harkonen T, Heide-Jorgensen MP (1990) Comparative life histories of East Atlantic and other harbor seal populations. Ophelia 32:211-235

Hastings KK, Frost KJ, Simpkins MA, Pendleton GW, Swain UG, Small RJ (2004) Regional differences in diving behavior of harbor seals in the Gulf of Alaska. Can J Zool 82: 1755-1773

Hedd A, Gales R, Renouf D (1995) Use of temperature telemetry to monitor ingestion by a harbour seal mother and her pup throughout lactation. Polar Biol 15:155-160

Herreman JK, Blundell GM, Ben-David M (2009a) Evidence of bottom-up control of diet driven by top-down processes in a declining harbor seal Phoca vitulina richardsi population. Mar Ecol Prog Ser 374:287-300

Herreman JK, Blundell GM, McDonald DB, Ben-David M (2009b) Asymmetrical male-mediated gene flow between harbor seal (Phoca vitulina) populations in Alaska. Can J Zool 87:498-507

> Hobson KA, Sease JL, Merrick RL, Piatt JF (1997) Investigating trophic relationships of pinnipeds in Alaska and Wash- 
ington using stable isotope ratios of nitrogen and carbon. Mar Mamm Sci 13:114-132

Hoover AA (1983) Behavior and ecology of harbor seals (Phoca vitulina richardsi) inhabiting glacial ice in Aialik Bay, Alaska. MS thesis, University of Alaska Fairbanks, Fairbanks, AK

Hoover-Miller AA (1994) Harbor seal (Phoca vitulina) biology and management in Alaska. Marine Mammal Commission, Washington, DC

Hoover-Miler AA, Akinson S, Conlon S, Prewitt J, Armato P (2011) Persistent decline in abundance of harbor seals Phoca vitulina richardsi over three decades in Aialik Bay, an Alaskan tidewater glacial fjord. Mar Ecol Prog Ser 424:259-271

Knowlton JL, Graham CH (2010) Using behavioral landscape ecology to predict species' responses to land-use and climate change. Biol Conserv 143:1342-1354

Kovacs KM, Lydersen C (2008) Climate change impacts on seals and whales in the North Atlantic Arctic and adjacent shelf seas. Sci Prog 91:117-150

Krutzikowsky GK, Emmett RL (2005) Diel differences in surface trawl fish catches off Oregon and Washington. Fish Res 71:365-371

Laidre KL, Stirling I, Lowry LF, Wiig O, Heide-Jogensen MP, Ferguson SH (2008) Quantifying the sensitivity of Arctic marine mammals to climate-induced habitat change. Ecol Appl 18:S97-S125

Lesage V, Hammill MO, Kovacs KM (2002) Diet-tissue fractionation of stable carbon and nitrogen isotopes in phocid seals. Mar Mamm Sci 18:182-193

Littell RC, Milliken GA, Stroup WW, Wolfinger RD, Schabenberger O (2006) SAS for mixed models, 2nd edn. SAS Institute, Cary, NC

Lowry LF, Frost KJ, Ver Hoef JM, DeLong RA (2001) Movements of satellite-tagged subadult and adult harbor seals in Prince William Sound, Alaska. Mar Mamm Sci 17: 835-861

Mathews EA, Pendleton GW (2006) Declines in harbor seal (Phoca vitulina) numbers in Glacier Bay National Park, Alaska, 1992-2002. Mar Mamm Sci 22:167-189

McCullagh P, Nelder JA (1989) Generalized linear models, 2nd edn. Chapman \& Hall, New York, NY

Mellish JE, Horning M, York AE (2007) Seasonal and spatial blubber depth changes in captive harbor seals (Phoca vitulina) and Steller's sea lions (Eumetopias jubatus). J Mammal 88:408-414

Molnia BF (2007) Late nineteenth to early twenty-first century behavior of Alaskan glaciers as indicators of changing regional climate. Global Planet Change 56:23-56

Moore SE, Huntington HP (2008) Arctic marine mammals and climate change: impacts and resilience. Ecol Appl 18: S157-S165
Mos L, Morsey B, Jeffries SJ, Yunker MB, Raverty S, De Guise S, Ross PS (2006) Chemical and biological pollution contribute to the immunological profiles of free-ranging harbor seals. Environ Toxicol Chem 25:3110-3117

Muelbert MMC, Bowen WD (1993) Duration of lactation and postweaning changes in mass and body composition of harbour seal, Phoca vitulina, pups. Can J Zool 71:1405-1414

Pauly D, Trites AW, Capuli E, Christensen V (1998) Diet composition and trophic levels of marine mammals. ICES J Mar Sci 55:467-481

Perrin WF, Würsig B, Thewissen JGM (eds) (2002) Encyclopedia of marine mammals. Academic Press, San Diego, CA

Pitcher KW (1986) Variation in blubber thickness of harbor seals in Southern Alaska. J Wildl Manag 50:463-466

Polyak L, Alley RB, Andrews JT, Brigham-Grette J and others (2010) History of sea ice in the Arctic. Quat Sci Rev 29: 1757-1778

Reilly JJ, Fedak MA (1990) Measurement of the body composition of living gray seals by hydrogen isotope dilution. $\mathrm{J}$ Appl Physiol 69:885-891

Robards M, Drew G, Piatt JF, Anson JM, Abookire A, Bodkin JL, Hooge P, Speckman S (2003) Ecology of selected marine communities in Glacier Bay: zooplankton, forage fish, seabirds and marine mammals. USGS Alaska Science Center, Anchorage, AK Available at: www.nps.gov/glba/naturescience/upload/Robards_et_al_Marine_Communities_ 2003.pdf

Rodrigues J (2009) The increase in the length of the ice-free season in the Arctic. Cold Reg Sci Technol 59:78-101

Ross PS (2000) Marine mammals as sentinels in ecological risk assessment. Hum Ecol Risk Assess 6:29-46

Shaughnessy PD, Fay FH (1977) A review of the taxonomy and nomenclature of North Pacific harbour seals. J Zool 182:385-419

Small RJ, Lowry LF, Ver Hoef JM, Frost KJ, DeLong RA, Rehberg MJ (2005) Differential movements by harbor seal pups in contrasting Alaska environments. Mar Mamm Sci 21:671-694

- Thompson PM, Wheeler H (2008) Photo-ID-based estimates of reproductive patterns in female harbor seals. Mar Mamm Sci 24:138-146

Tynan CT, DeMaster DP (1997) Observations and predictions of Arctic climate change: potential effects on marine mammals. Arctic 50:308-322

> Walker BG, Bowen WD (1993) Changes in body mass and feeding behaviour in male harbor seals, Phoca vitulina, in relation to female reproductive status. J Zool 231:423-436

> Womble JN, Pendleton GW, Mathews EA, Blundell GM, Bool NM, Gende SM (2010) Harbor seal (Phoca vitulina richardii) decline continues in the rapidly changing landscape of Glacier Bay National Park, Alaska 1992-2008. Mar Mamm Sci 26:686-697 


\section{Appendix 1.}

Table A1. Phoca vitulina richardii. Specifics of individual harbor seals captured and tagged with time-depth recorder tags (TDRs) in Glacier Bay National Park, Alaska, USA, including habitat in which they were captured and mean distance (km) traveled to forage, which was determined from focal follows while seals were foraging. Fidelity to the habitat in which seals were captured is indicated by comparing the number of days with location fixes from all non-foraging locations and the number of those days that fixes were in glacial habitat with the capture habitat for that seal. Average $( \pm \mathrm{SD})$ duration of days of radio tracking for individual seals to determine fidelity was $83.6 \pm 18.9 \mathrm{~d}$. F: female; M: male; A: Adult; J: juvenile; T: terrestrial; G: glacial

\begin{tabular}{|c|c|c|c|c|c|c|c|c|c|}
\hline Seal ID & Sex & Age & $\begin{array}{c}\text { Mean (range) } \\
\text { foraging distance }(\mathrm{km})\end{array}$ & $\begin{array}{l}\text { Capture } \\
\text { habitat }\end{array}$ & $\begin{array}{l}\text { No. o } \\
\text { Foraging }\end{array}$ & $\begin{array}{l}\text { of days with loc } \\
\text { Nonforaging }\end{array}$ & $\begin{array}{c}\text { cation fixes } \\
\text { Nonforaging } \\
\text { in glacial area }\end{array}$ & $\begin{array}{l}\text { Date of } \\
\text { first fix }\end{array}$ & $\begin{array}{l}\text { Date of } \\
\text { last fix }\end{array}$ \\
\hline $04 \mathrm{~GB} 02^{\mathrm{a}}$ & $\mathrm{F}$ & $\mathrm{A}$ & $0.93(0.28-0.98)$ & $\mathrm{T}$ & 2 & 25 & 0 & 24 Apr 04 & $15 \mathrm{Jul} 04$ \\
\hline $04 \mathrm{~GB} 3^{\mathrm{a}}$ & F & $\mathrm{A}$ & $1.05(1.01-1.08)$ & $\mathrm{T}$ & 2 & 23 & 0 & 24 Apr 04 & $12 \mathrm{Jul} 04$ \\
\hline $04 \mathrm{~GB} 05^{\mathrm{a}}$ & F & $\mathrm{A}$ & $1.7(0.13-5.35)$ & $\mathrm{T}$ & 5 & 53 & 0 & 26 Apr 04 & $23 \mathrm{Jul} 04$ \\
\hline $04 \mathrm{~GB}^{2} 8^{\mathrm{a}}$ & F & A & $1.41(0.36-2.45)$ & $\mathrm{T}$ & 2 & 37 & 0 & 25 Apr 04 & $28 \mathrm{Jul} 04$ \\
\hline $04 \mathrm{~GB} 16^{\mathrm{a}}$ & F & $\mathrm{A}$ & $6.2(5.8-6.69)$ & $\mathrm{T}$ & 3 & 49 & 2 & 25 Apr 04 & $24 \mathrm{Jul} 04$ \\
\hline $05 \mathrm{~GB} 6^{\mathrm{a}}$ & $\mathrm{F}$ & $\mathrm{A}$ & $7.65(6.64-8.95)$ & $\mathrm{T}$ & 2 & 37 & 0 & 03 May 05 & $15 \mathrm{Jul} 05$ \\
\hline $05 \mathrm{~GB} 12^{\mathrm{a}}$ & $\mathrm{F}$ & $\mathrm{A}$ & $4.59(4.17-5.0)$ & $\mathrm{T}$ & 2 & 45 & 0 & 03 May 05 & $21 \mathrm{Jul} 05$ \\
\hline $06 \mathrm{~GB} 23^{\mathrm{a}}$ & $\mathrm{F}$ & $\mathrm{A}$ & $9.75(3.98-15.9)$ & $\mathrm{T}$ & 6 & 10 & 0 & 09 May 06 & $29 \mathrm{Jul} 06$ \\
\hline 04GB04 & $\mathrm{F}$ & $\mathrm{A}$ & $0.99(0.88-1.1)$ & $\mathrm{T}$ & 2 & 18 & 0 & 26 Apr 04 & $23 \mathrm{Jul} 04$ \\
\hline 04GB14 & $\mathrm{F}$ & A & $26.98(23.8-30.16)$ & $\mathrm{T}$ & 2 & 41 & 0 & 26 Apr 04 & $29 \mathrm{Jul} 04$ \\
\hline $06 \mathrm{~GB} 24^{\mathrm{b}}$ & $\mathrm{F}$ & $\mathrm{A}$ & & $\mathrm{T}$ & & 5 & 0 & 09 May 06 & $10 \mathrm{Jul} 06$ \\
\hline 04GB06 & $\mathrm{F}$ & $\mathrm{J}$ & $1.8(0.18-4.0)$ & $\mathrm{T}$ & 4 & 54 & 0 & 26 Apr 04 & 07 Jul 04 \\
\hline $04 \mathrm{~GB} 11$ & $\mathrm{~F}$ & $\mathrm{~J}$ & 0.83 & $\mathrm{~T}$ & 1 & 9 & 0 & 07 May 04 & 30 Jun 04 \\
\hline $06 \mathrm{~GB} 25$ & $\mathrm{~F}$ & $\mathrm{~J}$ & $1.38(1.19-1.56)$ & $\mathrm{T}$ & 2 & 6 & 0 & 11 May 06 & 26 Jun 06 \\
\hline $05 \mathrm{~GB} 16$ & M & $\mathrm{A}$ & $3.52(1.79-5.88)$ & $\mathrm{T}$ & 4 & 82 & 0 & 03 May 05 & 12 Aug 05 \\
\hline $05 \mathrm{~GB} 17$ & M & $\mathrm{A}$ & 5.69 & $\mathrm{~T}$ & 1 & 20 & 0 & 04 May 05 & 01 Aug 05 \\
\hline $05 \mathrm{~GB} 15$ & M & $\mathrm{A}$ & $2.72(2.61-2.83)$ & $\mathrm{T}$ & 2 & 68 & 0 & 05 May 05 & 21 Aug 05 \\
\hline 06GB20 & M & $\mathrm{A}$ & $8.07(7.41-10.03)$ & $\mathrm{T}$ & 5 & 9 & 0 & 25 May 06 & 09 Aug 06 \\
\hline 06GB28 & M & $\mathrm{A}$ & $8.67(8.46-8.78)$ & $\mathrm{T}$ & 5 & 9 & 0 & 11 May 06 & 07 Aug 06 \\
\hline $06 \mathrm{~GB} 13^{\mathrm{a}}$ & $\mathrm{F}$ & $\mathrm{A}$ & 53.69 & G & 1 & 41 & 41 & 30 May 06 & 31 Aug 06 \\
\hline $06 \mathrm{~GB} 14^{\mathrm{a}, \mathrm{b}}$ & $F$ & $\mathrm{~A}$ & & G & & 59 & 59 & 09 May 06 & 19 Aug 06 \\
\hline 05GB24 & $\mathrm{F}$ & $\mathrm{J}$ & 1.88 & G & 1 & 7 & 7 & 03 May 05 & 09 Aug 05 \\
\hline $05 \mathrm{~GB} 25$ & $\mathrm{~F}$ & $\mathrm{~J}$ & $15.8(6.99-20.49)$ & $\mathrm{G}$ & 3 & 25 & 7 & 08 May 05 & 08 Aug 05 \\
\hline $05 \mathrm{~GB}_{2} 9^{\mathrm{b}}$ & $\mathrm{F}$ & $\mathrm{J}$ & & G & & 14 & 5 & 03 May 05 & 25 Aug 05 \\
\hline 06GB05 & $\mathrm{F}$ & $\mathrm{J}$ & 12.6 & G & 1 & 28 & 28 & 22 May 06 & 30 Jul 06 \\
\hline 06GB11 & $\mathrm{F}$ & $\mathrm{J}$ & 12.32 & G & 1 & 11 & 11 & 30 May 06 & 24 Jun 06 \\
\hline $06 \mathrm{~GB} 18^{\mathrm{b}}$ & $\mathrm{F}$ & $\mathrm{J}$ & & G & & 10 & 10 & 09 May 06 & 07 Jul 06 \\
\hline
\end{tabular}

Editorial responsibility: Hans Heinrich Janssen, Oldendorf/Luhe, Germany
Submitted: August 15, 2010; Accepted: February 3, 2011 Proofs received from author(s): April 26, 2011 